\title{
Water Rocket - Electrolysis Propulsion and Fuel Cell Power
}

F. Mitlitsky, A.H. Weisberg, P.H. Carter, M.D. Dittman, B. Myers, R.W. Humble, J.T. Kare

This article was submitted to

American Institute of Aeronautics and Astronautics Space Technology Conference and Exposition, Albuquerque, NM, September 28-30, 1999

\section{July 24, 1999}

U.S. Department of Energy

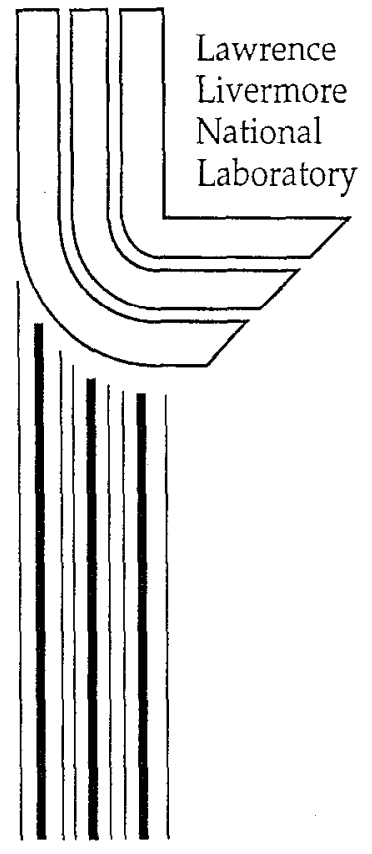




\section{DISCLAIMER}

This document was prepared as an account of work sponsored by an agency of the United States Government. Neither the United States Government nor the University of California nor any of their employees, makes any warranty, express or implied, or assumes any legal liability or responsibility for the accuracy, completeness, or usefulness of any information, apparatus, product, or process

disclosed, or represents that its use would not infringe privately owned rights. Reference herein to any specific commercial product, process, or service by trade name, trademark, manufacturer, or otherwise, does not necessarily constitute or imply its endorsement, recommendation, or favoring by the United States Government or the University of California. The views and opinions of authors expressed herein do not necessarily state or reflect those of the United States Government or the University of California, and shall not be used for advertising or product endorsement purposes. 


\title{
WATER ROCKET - ELECTROLYSIS PROPULSION AND FUEL CELL POWER
}

\author{
F. Mitlitsky*, A.H. Weisberg*, P.H. Carter*, M.D. Dittman*, and B. Myers ${ }^{\dagger}$, \\ Lawrence Livermore National Laboratory, L-174, Livermore, CA 94551-0808; fm@1lnl.gov \\ R.W. Humble* \\ Astronautics Department, United States Air Force Academy, Colorado Springs, CO \\ J.T. Kare* \\ Kare 'I'echnical Consulting, San Kamon, CA
}

\begin{abstract}
Water Rocket is the collective name for an integrated set of technologies that offer new options for spacecraft propulsion, power, energy storage, and structure. Low pressure water stored on the spacecraft is electrolyzed to generate, separate, and pressurize gaseous hydrogen and oxygen. These gases, stored in lightweight pressure tanks, can be burned to generate thrust or recombined to produce electric power. As a rocket propulsion system, Water Rocket provides the highest feasible chemical specific impulse ( 400 seconds). Even higher specific impulse propulsion can be achicved by combining Watcr Rocket with other advanced propulsion technologies, such as arcjet or electric thrusters. With innovative pressure tank technology, Water Rocket's specific energy [Wh/kg] can exceed that of the best foreseeable batteries by an order of magnitude, and the tanks can often serve as vehicle structural elements. For pulsed power applications, Water Rocket propellants can be used to drive very high power density generators, such as MHD devices or detonationdriven pulse generators. A space vehicle using Water Rocket propulsion can be totally inert and non-hazardous during assembly and launch. These features are particularly important for the timely development and flight qualification of new classes of spacecraft, such as microsats, nanosats, and refuelable spacecraft.
\end{abstract}

\section{Introduction}

New options for spacecraft propulsion, power, energy storage, and structure are enabled by an integrated suite of technologies known as Water Rocket. High Isp propellants can be generated, separated, and pressurized on-the-fly by the electrolysis of low pressure water. Water can also be the medium for high energy density electrical energy storage. The same hardware and resources are used for propulsion and energy storage, allowing operational water allocation decisions to be made during the mission. In many mission scenarios, solar cells can be used opportunistically to produce propellants (or generate reactants to store electrical energy), so that Water Rocket can be implemented without adding solar cells beyond payload requirements. The pressure vessels required for storing propellants (or reactants) often will be strong enough to serve as vehicle structure. Mass savings from subsystems with multiple functions expand the range of missions for which Water Rocket is advantageous. The core of that range comes from the best chemical Isp available from storable propellants. This range of applications is a ncw niche for spacceraft, allowing the rapid maneuvers of chemical thrusters but obtaining the energy for propulsion by accumulating solar power.

A Water Rocket space vehicle may be totally inert and nonhazardous at launch. Minimal insulation and redundant layers of leak sealing make a Water Rocket designed to launch unpressurized entirely harmless to other equipment, and essentially unregulated. Thus Water Rocket enables rapid prototyping and space testing of space vehicles without long delays caused by range safety (or Shuttle safety) concerns. This is particularly important for the timely development of microsats and nanosats.

Water Rocket's capability for high Isp propulsion, combined with the low mass overhead required to store unpressurized water, can take secondary payloads through large total- $\Delta \mathrm{V}$ missions. As long as the total- $\Delta \mathrm{V}$ requirement of a mission can be broken up into several burns, allowing gas tanks to be refilled several times during a mission, Water Rocket outperforms (in preliminary, unbiased comparisons) conventional chemical propulsion (due to propellant mass savings) for total-mission- $\Delta \mathrm{V}$ above $\sim 1.3 \mathrm{~km} / \mathrm{s}$. This is particularly attractive in orbit transfer, satellite repositioning, lunar, and Earth-escaping missions.

* Member AIAA

$\uparrow$ Associate Fellow AIAA

Copyright (c) 1999 by the American Institute of

Aeronautics and Astronautics, Inc. All rights reserved. 


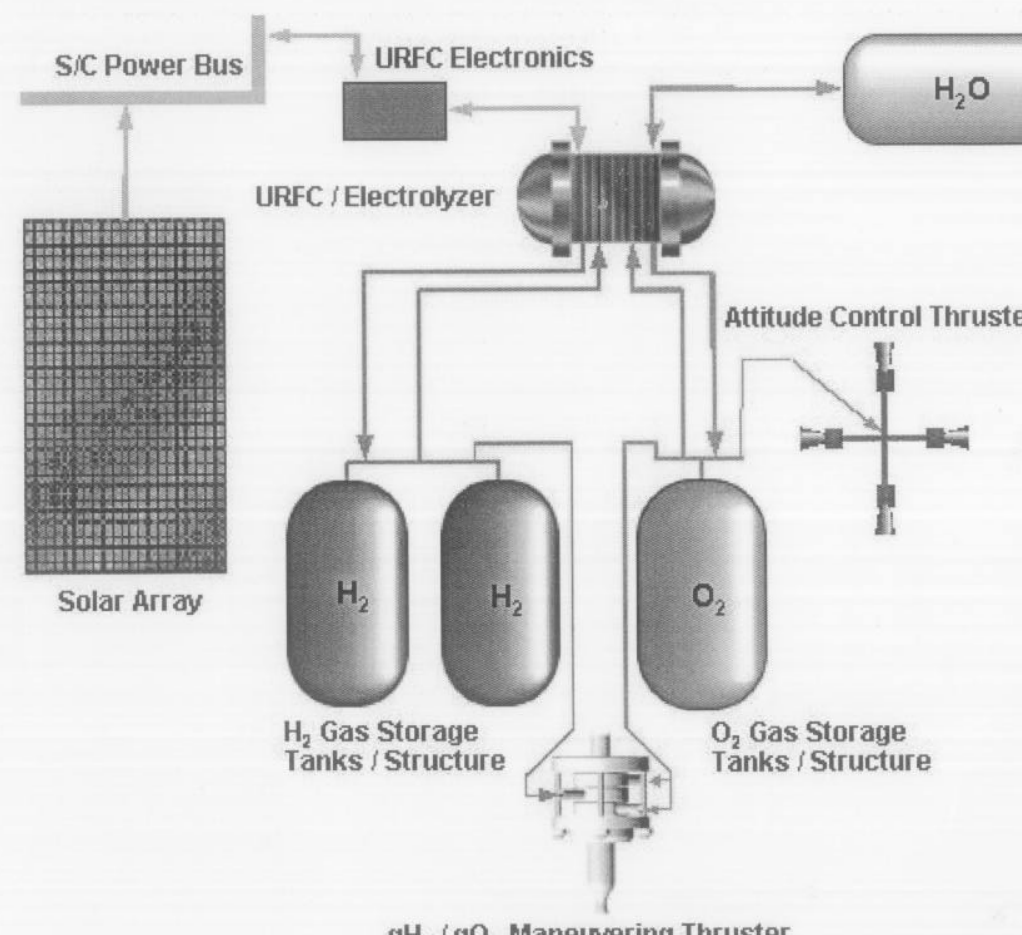

$\mathrm{gH}_{2} / \mathrm{gO}_{2}$ Maneuvering Thruster

Bladder Expulsion Tank / Structure

URFC Electrochemistry Using Proton Exchange Membrane (PEM) Fuel Cell (Discharge)

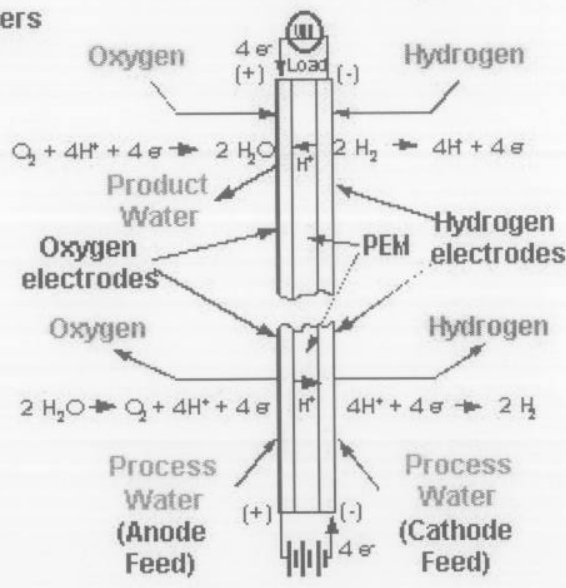

Electrolyzer (Charge)

Figure 1. Schematic of Water Rocket and Unitized Regenerative Fuel Cell (URFC)

Besides enabling high total- $\Delta \mathrm{V}$ missions for secondary payloads and enabling missions with energy storage requirements that would demand excessive battery weight, Water Rocket is the best approach to refuelable spacecraft because water is very easy to handle. Several key aspects of Water Rocket systems are summarized below:

- Low pressure water electrolyzes into $\mathrm{H}_{2} / \mathrm{O}_{2}$ gases at pressures up to several $\mathrm{ksi}$; no moving parts are required using some zero-g electrochemical stack designs

- Vacuum specific impulse (Isp vac.) of $>380$ seconds is feasible for near-stoichiometric $\mathrm{gH}_{2} / \mathrm{gO}_{2}$ engines (stoichiometric for water is 2 moles of $\mathrm{H}_{2}$ for each mole of $\mathrm{O}_{2}$ or oxidizer/fuel mass ratio=7.94)

- Several $\mathrm{km} / \mathrm{s}$ mission $\Delta \mathrm{V}$ is feasible, mission $\Delta \mathrm{V}$ above $\sim 1.3 \mathrm{~km} / \mathrm{s}$ advantageous

- Multiple hot burns of tens to hundreds of meters/s increase Water Rocket advantages

- Developed, stable, long life designs for $\mathrm{gH}_{2} / \mathrm{gO}_{2}$ engines can provide a wide range of thrust levels

- Non-toxic propellants and unpressurized tanks create a non-hazardous space vehicle at launch

- Integration costs and delays are minimal for inert, nonhazardous-at-launch Water Rockets

- Water is ideal for indefinite storage, at low pressure, with minimal container mass overhead
- Unitized regenerative fuel cell (URFC) is both a propellant generator when operated as an electrolyzer, and an electrical power producer, when operated as a fuel cell

- URFC specific energy (Wh/kg) offers up to an order of magnitude improvement over batteries

- Mass fractions can be dramatically improved for systems requiring relatively massive batteries

- Integration of structure and tankage allows additional mass fraction improvement

A schematic of Water Rocket and URFC operation is shown in Figure 1.

Lawrence Livermore National Laboratory (LLNL) initiated the design and development of a Water Rocket Propulsion Subsystem in 1998, with the assistance of: the Air Force Research Laboratory (AFRL), the United States Air Force Academy (USAFA), the European Air Force Office of Research and Development (EAORD), and NASA Glenn Research Center (GRC), and various industrial partners, including United Technologies Hamilton Standard Division (HS), Schafer Corporation, Thiokol Corporation, Aero Tec Laboratories Inc. (ATL), RAND Corporation, and Southern Research Institute (SRI), and several consultants. 


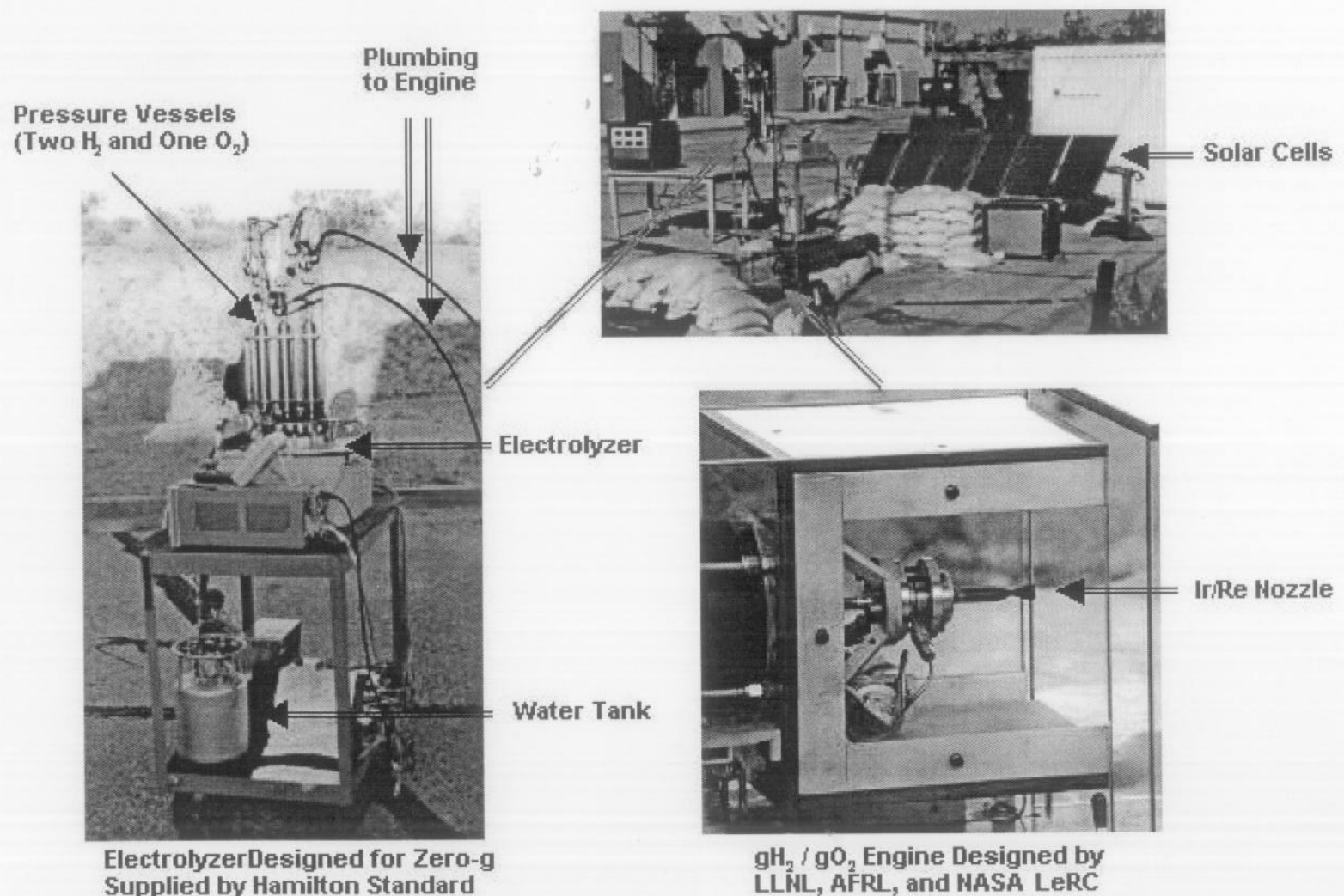

Figure 2. Solar Powered Water Rocket Brassboard Demonstration at AFRL Edwards AFB, CA on 11/6/98

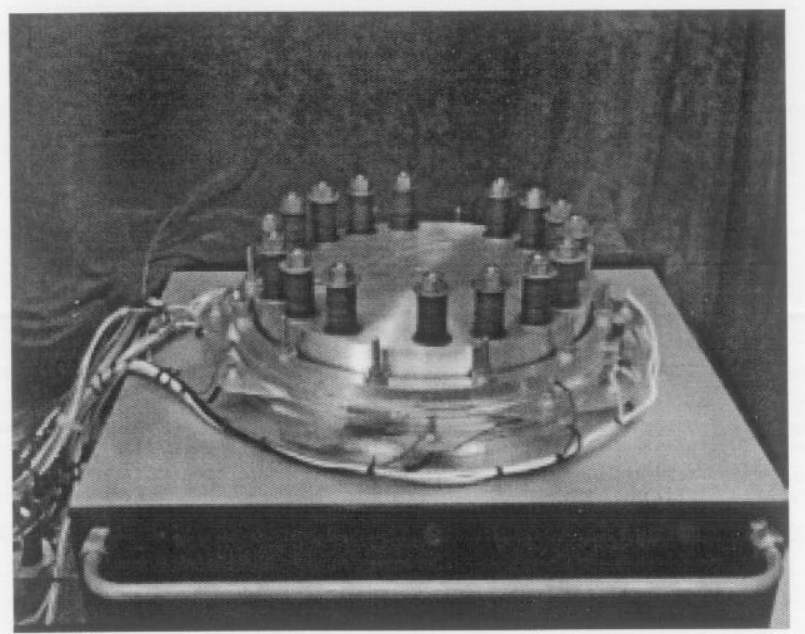

Figure 3. Zero-g Capable Static Feed Electrolyzer

LLNL facilitated copious communication within this diverse team to understand design issues, update trade studies, evaluate the capabilities of Water Rocket Systems, and evaluate mission niches where the positive attributes of Water Rocket Systems could facilitate the space needs of the US government (especially the
USAF). This team also determined the state-of-the-art (SOA) for the key components of Water Rocket Systems, and initiated a program plan that could develop and demonstrate the technologies required for a flight-worthy system. Examples of the appropriate component technologies were assembled and integrated for the first time. This team put together and operated a functionally complete Water Rocket hardware brassboard in November 1998, which demonstrated solar-powered electrolytic gas generation using a zero-g capable electrolyzer, pressurized storage of the electrolyzed gases, and combustion of those gases in a 1.1 Newton $(0.25 \mathrm{lbf})$ thruster (Figure 2). A close-up photo of the zero-g capable static feed electrolyzer is shown in Figure 3.

AFRL provided a wealth of information related to $\mathrm{gH}_{2} / \mathrm{gO}_{2}$ engine development and testing. AFRL designed several important elements in the prototype engine used for the brassboard. AFRL recommended several key personnel on this team, and donated personnel to support, evaluate, and provide valuable feedback. Their brassboard safety and testing advice was particularly valuable, and a parking lot with suitable approvals at AFRL's Edwards Propulsion facility provided the site for the Water Rocket brassboard demonstration. 
In addition to the brassboard demonstration itself; major accomplishments of the team included:

- Preliminary design of a lightweight zero-g electrolyzer capable of converting low pressure (several psi) water into high pressure (2 ksi) hydrogen and oxygen. Preliminary designs were performed for systems with peak electric input power levels of 50 watt, 100 watt, and 200 watt. A detailed design was developed for a 200 watt electrolyzer system, and a preliminary design for a URFC. system. The URFC system design was based on the 200 watt electrolyzer, and is capable of generating a peak electrical output power of $\sim 100$ watt. The final report estimates a stack weight of $2.8 \mathrm{lb}(1.3 \mathrm{~kg})$ for the electrolyzer stack or $-3.5 \mathrm{lb}(1.6 \mathrm{~kg})$ for the URFC option.

- Reactivation of a Hamilton Standard static feed water electrolyzer designed for zero-gravity environments. This unit uses an electrochemical hydrogen pump, allowing hydrogen pressure to exceed water pressure. It was manufactured in the mid-1980's and remained in storage for a dozen years before being activated in 1998 to implement the brassboard. Its performance in 1998 duplicated the performance obtained in the mid-1980's. Several units containing up to seven cells were tested during the 1980's, accumulating many thousands of hours of experience. This demonstrator unit is rated at 200 psi gas generation pressure. The same basic design with re-enforced frames has been demonstrated successfully at $1000 \mathrm{psi}$ at NASA Marshall Space Flight Center. $^{13}$

- Preliminary mission analysis of a mission enabled by Water Rocket called "Blue Moon". Blue Moon is a space mission being developed at USAFA in conjunction with LLNL and the European Air Force Office of Research and Development (EAORD). This project is part of an ongoing effort to teach future Air Force officers how to develop spacecraft and to fly space missions as part of USAFA's overall mission to "Develop and inspire air and space leaders with a vision for tomorrow". The technical goals for Blue Moon are twofold: First to demonstrate Department of Defense (DOD) critical propulsion and power technology related to Water Rocket, and second to contribute to the world's scientific knowledge of Earth's moon.

- Development of a new, highly flexible experimental $\mathrm{gH}_{2} / \mathrm{gO}_{2}$ thruster, using a NASA LeRC iridium coated rhenium (Ir/Re) 0.25 lbf nozzle for the initial demonstration, but capable of adapting to thrust levels up to $5 \mathrm{lbf}$ and to a wide range of ignition, injection, and film cooling options.

- Preliminary analysis of improved-Isp stoichiometric thruster options using oxygen film cooling. This analysis made use of a wealth of historical information and expertise on $\mathrm{gH}_{2} / \mathrm{gO}_{2}$ engine development and testing supplied by NASA LeRC. To date this work has been done with significant hydrogen film cooling for nearstoichiometric mixtures. Hydrogen functions as a cooling film that not only lowers the wall temperature, but also scavenges oxygen molecules and atoms that penetrate towards the wall. This allows engine wall temperatures to go significantly higher with hydrogen film cooling than with oxygen film cooling. With oxygen film cooling, wall temperatures have to be kept low across the full thruster. Because extensive thruster heating always occurs in the contraction region ahead of the throat, this region should be the focus of the thruster design. To restrict temperatures to levels which theoretically provide wall protection, the thruster must be kept short. This requirement needs to be balanced with the requirement that full reaction takes place within the chamber.

A parametric analytical study was performed to assess the feasibility of an oxygen film cooled $\mathrm{gH}_{2} / \mathrm{gO}_{2}$ engine. The results reflect a high potential for improved overall system performance and wall compatibility by utilizing oxygen film cooling vs. hydrogen in a near-stoichiometric $\mathrm{gH}_{2} / \mathrm{gO}_{2}$ system. ${ }^{14}$ Delivered vacuum Isp of 400 seconds and greater may be achieved through higher expansion area ratio and/or chamber pressure.

- Fabrication of minimum gauge composite tubes to determine the feasibility of advanced lightweight tank designs. All tubes in this work are 5.0" ID fabricated with T1000G graphite composite with fibers oriented $+/-60$ degrees from the axis. Thiokol demonstrated a single ply layup with wall thickness of 0.011 " and a two ply layup with wall thickness of 0.023 ". The project demonstrated a single ply wrapped version with wall thickness of 0.019 ". The 0.023 " wall tube should be capable of 2500 psi burst, which is ideally suited to the static feed electrolyzer and URFC designs (Figure 4 upper left). Related tankage for hydrogen fueled automobiles is being developed in work funded by DOE. That effort has recently demonstrated a minimum gauge prototype tank wound onto a 12" ID lightweight molded liner (Figure 4 lower left). The composite wall thickness of this tank is estimated to be 0.035 ". 

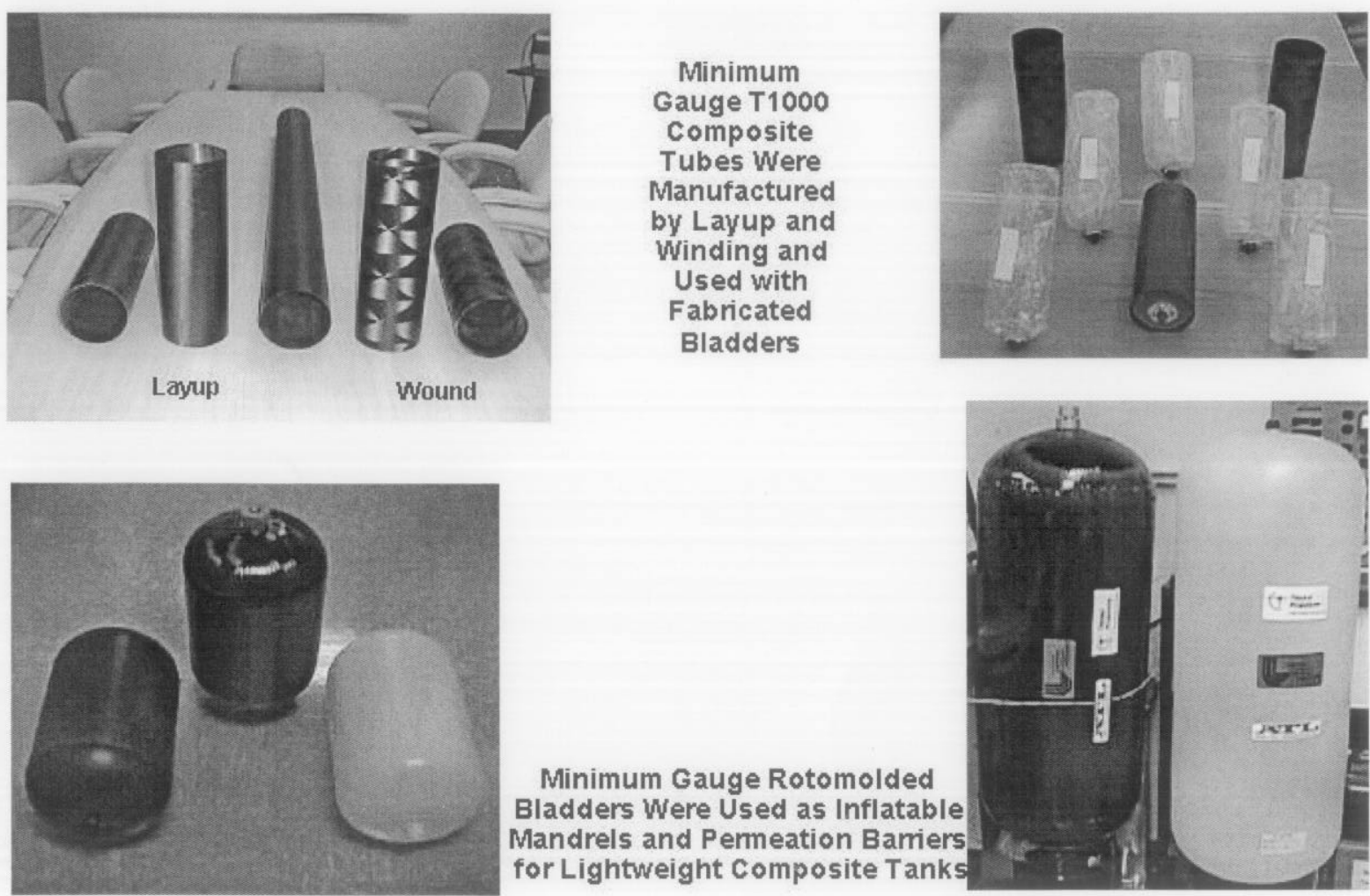

Minimum Gauge Rotomolded Bladders Were Used as Inflatable Mandrels and Permeation Barriers. for Lightweight Composite Tanks

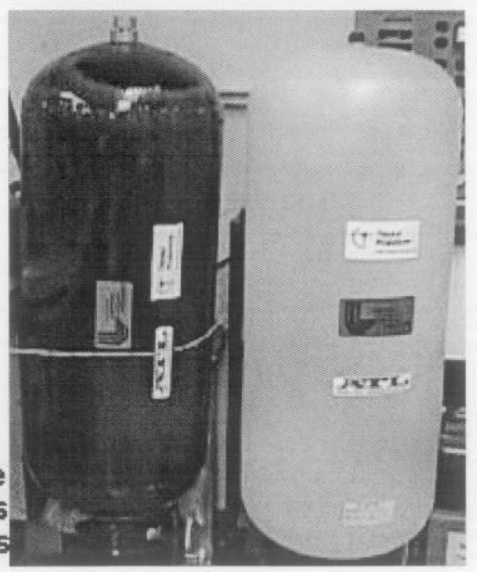

Figure 4. Lightweight Bladder-Lined Tankage was Prototyped using Molded or Fabricated Liners

A series of thin prototype liners were fabricated (Figure 4 upper right), using polymers with expected low hydrogen permeation, for demonstrating LLNL's lightweight 5" strut tank designs. Minimum gauge molded liners were fabricated for LLNL's DOE funded program that is developing related lightweight tankage. In late 1997, Aero Tec Laboratories (ATL) and LLNL jointly developed 5" cylindrical bladder expulsion tankage for hydrogen peroxide $\left(\mathrm{H}_{2} \mathrm{O}_{2}\right)$ that would be ideal for Water Rocket's water expulsion. This expulsion technology controls center of mass location within a millimeter or so, expels over $99 \%$ of the contained liquid, exposes the contained liquid only to fittings and Teflon-like polymers, and imposes less than $1 \%$ mass penalty to hold unpressurized water. The team also fabricated a series of thin prototype liners using polymers with low hydrogen and oxygen permeation to demonstrate LLNL's lightweight tank designs, and is compiling a large database on hydrogen permeation over a wide range of temperatures and strains and up to $5 \mathrm{ksi}$ pressure differential.

A lightweight hydrogen tank was designed and prototyped for automotive applications which require 5000 psi operation (35 MPa) with safety factor of 2.25 (Figure 4 lower right). The estimated burst pressure $(\mathrm{Pb})$ for this prototype was $11,250 \mathrm{psi}(78 \mathrm{MPa})$. The prototype tank was proof tested to $7500 \mathrm{psi}$ (52 MPa). The tank weight (W) is $54.1 \mathrm{lb}$ including 2 bosses and one end plug. The internal volume (V) is 9247 in $^{3}$ (151 liter) at ambient pressure. The internal volume is estimated to be $9525 \mathrm{in}^{3}$ (156 liter) at operating pressure. The estimated tank performance factor $(\mathrm{PbV} / \mathrm{W})$ is $\sim 1.9 \mathrm{E} 6$ inch $(49 \mathrm{~km})$. This tank could store $>12 \% \mathrm{H}_{2}$ by weight at $300 \mathrm{~K}^{15}$

- Performed preliminary mission analysis work for candidate Water Rocket missions and commenced the difficult task of trying to compare and contrast Water Rocket's features against a host of other propulsion technologies. Three classes of missions were examined:

1-Orbit Transfer (a small number of preplanned large delta-V maneuvers conducted soon after launch, so nonstorable propellants and solid rockets are reasonable). The Blue Moon Mission details this type of mission.

2-Operational Maneuver (an undetermined number of moderate to large delta- $\mathrm{V}$ maneuvers conducted over the life of a mission, so storable propellants are required and solid rockets not acceptable). One example of this type of mission is a space-based radar system such as the DARPA Radarsat, which can gain substantial performance by 
- Assumptions:

- Vehicle initial gross mass $\left(M_{o}\right)$ is $100 \mathrm{~kg}$

- $90 \mathrm{~N}$ (20 lbf) thruster

- Demonstrated water rocket modeling assumptions

"Cylindrical tanks with bladder-lined carbon fiber composite overwrap

》) Aspect ratio $a / b=2$

" Gas tanks hold $1 \mathrm{~kg}\left(\mathrm{M}_{\mathrm{eb}}\right)$ of propellant at operating pressure, $\left(\mathrm{M}_{\mathrm{eb}} / \mathrm{M}_{\mathrm{o}}=.01\right)$

» $I_{\text {sp }}=380 \mathrm{~s}$

" MF $=72 \%(1300 \mathrm{~m} / \mathrm{s}), 82 \%(3000 \mathrm{~m} / \mathrm{s})$

- Typical "Best in Class" assumptions for $I_{s p} \&$ Mass Fraction (MF) for other propulsion technologies

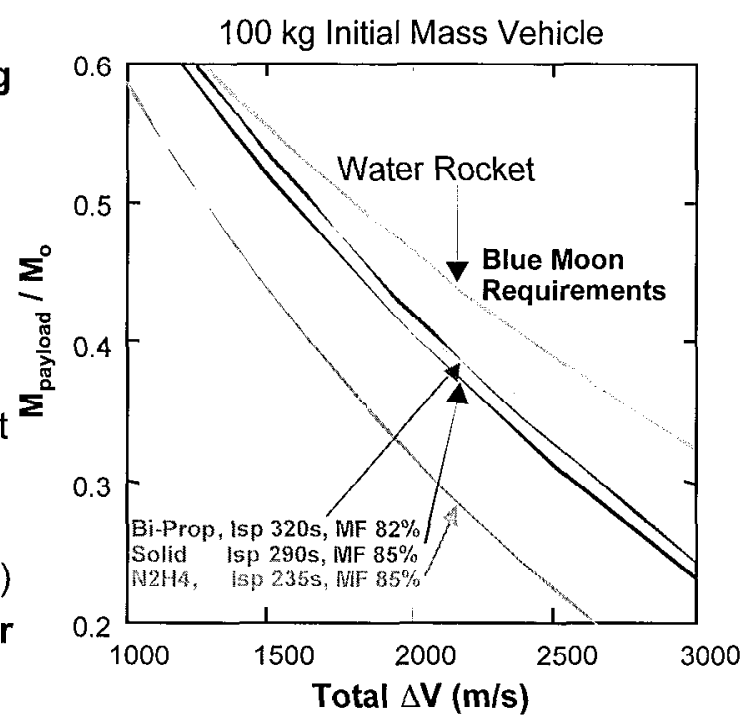

" MF considered constant Water Rocket performance is better than
other traditional propulsion technologies

Water Rocket presents no pressure hazards, toxic hazards, or flammability hazards to the launch vehicle or primary payload

Figure 5. Water Rocket Propulsion Performance Comparison - Blue Moon Mission Example

changing orbital inclination on demand to optimize coverage of a crisis area.

3- $\Lambda$ CS (attitude control type missions with many small delta-V maneuvers for drag makeup, stationkeeping, and attitude control, so small minimum bit is critical). ${ }^{16}$

System studies were performed to size Water Rocket and to assess its performance in comparison to several other technologies. These studies required predictive mass models of components and subsystems that have yet to be built or tested in flightweight form. Those mass models were conservative, and the competitors' mass performance assumptions were given the benefits of foreseeable improvements in order to unequivocally establish the advantages of Water Rocket for these classes of missions. One such mission studied in detail was the Blue Moon mission. This mission assumed that a $100 \mathrm{~kg}$ initial gross mass $\left(M_{0}\right)$ spacecraft would be launched as a benign secondary payload to GTO. Once dropped off, it required enough delta- $V$ to achieve trans-lunar injection, mid-course corrections, lunar capture, lunar orbital maintenance, attitude control, and finally a deorbit burn. The total mission delta- $V$ required was estimated to be $\sim 2.1 \mathrm{~km} / \mathrm{s}$ including margin. Additionally, the entire spacecraft is required to present no hazard to the primary payload. Water Rocket performance was shown to be better than other traditional propulsion technologies, while achieving the necessary attributes for a secondary payload (Figure 5).

\section{Proton Exchange Membrane (PEM) Electrolysis}

Proton Exchange Membrane (PEM) electrolysis produces both hydrogen and oxygen, in the exact stoichiometric proportion that fuel cells consume. Electrolyzers with operational pressures up to 3000 psi (20.7 MPa) are currently used for US Navy submarine oxygen generators. An aerospace version has been demonstrated in the Integrated Propulsion Test Article (IPTA) program. Electrolyzers with operational pressures up to 6000 psi (41.4 MPa) have also been demonstrated in the High Pressure Oxygen Recharge System (HPORS). Onboard oxygen generator systems (OBOGS) that generate up to 2000 psi $(13.8 \mathrm{MPa})$ oxygen and refill breathable oxygen tanks for commercial aviation have been designed and successfully demonstrated. ${ }^{13}$ Other hardware applications that require high pressure PEM devices are related to these proven applications.

Many PFM cell designs require pumps, but the simplest system variants can eliminate all moving parts (except the

6

American Institute of Aeronautics and Astronautics 
poppets inside valves and water expulsion containers) by suitable modifications to the electrolysis cell itself. Electrolyzers that do not require a high pressure or circulating pump, known as "static feed" electrolyzers, have been developed for use with propellant generators for small satellites since the mid-1970's. Up to 1000 psi (6.9 $\mathrm{MPa}$ ) hydrogen and oxygen gas generation pressures have been demonstrated using high pressure water. Hamilton Standard (HS) has since improved this capability with proprietary cell designs that can produce high gas pressures from low pressure water.

LLNL adopted a reversible aerospace PEM technology, available only from HS before 1998, in order to solve the very challenging problem of propelling a solar power aircraft through the night. The extreme weight-sensitivity of this advanced vehicle application favors the combination of electrolysis and fuel cell modes of operation in the same PEM cell design. PEM static feed reversible (unitized) fuel cells (URFCs) were demonstrated (over 700 cycles, 2.1 $\mathrm{MPa}$ ) for small satellite energy storage. ${ }^{1-4}$ More recent testing at LLNL proved high cycle life ( $>2000$ cycles) and high performance URFCs. ${ }^{2-5}$

\section{Static Feed PEM Electrolyzer \& Reversible Cell Design}

Static water feed electrolysis is an innovation that can generate high pressure gases without pumps. This form of electrolysis transports water (by osmosis and diffusion) between the water chamber and the oxygen electrode, where electrolysis occurs. The generated hydrogen gas diffuses into the water chamber and must be prevented from masking the water feed barrier from the water supply. Two approaches for preventing water feed barrier masking have been demonstraled. One approach maintains the water pressure above hydrogen pressure, preventing hydrogen gas from coming out of solution. The other approach uses an electrochemical hydrogen pump that returns hydrogen to the hydrogen cavity to prevent its accumulation on the water side, and thereby allows operation with a low pressure water fecd. ${ }^{4,6}$ The diffusion of hydrogen and oxygen gas through the electrolysis cell is a loss mechanism, but does not form explosive gas mixturcs since the diffusing gases react on the same catalyst which split protons from water. Reaction heat is conducted away from the cell to an external heat sink by a metal foil. Hamilton Standard static feed cells use edge current collection and can be stacked in electrical series by external connections.

\section{Advanced High Pressure PEM Systems}

The development of the hydrogen-oxygen-water electrochemical system is sufficiently perfected technologically to contribute to the achievement of many aernspace goals. The last ten years of progress have shown significant advances in electrolyzer hardware development, mostly with respect to inherent maximum cell stack operating pressure, unaided by pressure domes or other auxiliary equipment. Today's technology makes possible electrolyzer assemblies that directly generate the gases at up to tank storage pressure (tested to $12 \mathrm{MPa}$ for terrestrial applications) with only the additional stack weight required to contain the pressure. There is an overall weight savings at the system level when compared with earlier designs, due to the elimination of a number of support components. This new electrolyzer hardware capability is very attractive for small craft propulsion when it is deemed practical to produce gases in-situ. For spacecraft applications, water is easy to store and launch, while the specific impulse of hydrogen-oxygen thrusters is superior to all other nontoxic propellant combinations. Producing propellant as needed also reduces the storage volume required, a significant bonus of this high-pressure technology. ${ }^{4,5-12}$

A trade study was performed by Hamilton Standard in support of LLNL spacecraft applications. Its deliverables included three preliminary designs of lightweight, high pressure PEM electrolyzers. Static Feed PEM electrolyzers with nominal electrical power inputs of 50, 100, and 200 $\mathrm{W}$, were sized in sufficient detail to predict all component masses. Prior technology that could address the same applications includes vapor feed and high pressure anode feed electrolyzers. In 1986 a vapor feed electrolyzer was assembled with polysulfone frames and a series of electrical and thermal conducting rings. More recently, anode feed electrolyzers have been tested that provide higher pressure capability than the polysulfone frame design at lower weight per cell. These two types of proven electrolyzers were incorporated into a cell design that supplies high pressure oxygen and hydrogen free of liquid water. This has been accomplished using the Hamilton Standard static feed electrolysis cell configuration and high pressure hardware design.

Requirements for the cell stack design included production of hydrogen and oxygen at 2000 psi (13.8 MPa), with water supplied at ambient pressure, long operating life, and as lightweight as practical. Thrce separate cells were designed for three different power ratings, with active areas of $22.2 \mathrm{in}^{2}\left(143 \mathrm{~cm}^{2}\right), 44.5 \mathrm{in}^{2}\left(287 \mathrm{~cm}^{2}\right)$, and $88.9 \mathrm{in}^{2}$ $\left(574 \mathrm{~cm}^{2}\right)$. The $50 \mathrm{~W}, 100 \mathrm{~W}$, and $200 \mathrm{~W}$ designs use the same 16 cell arrangement, so that the voltage drop for each stack was held constant across all three designs. Each cell is equipped with thermal management provisions in the form of heat conduction tabs to carry heat out of the stack, 
Table 1: Conceptual Design of $2000 \mathrm{psi}$ (13.8 MPa) Static Water Feed Electrolyzer

\begin{tabular}{|l|c|c|c|}
\hline Input Power & 50 Watt & 100 Watt & 200 Watt \\
\hline Number of Cells & 16 & 16 & 16 \\
\hline Active Area/cell $\left[\mathrm{in}^{2}\left(\mathrm{~cm}^{2}\right)\right]$ & $1.39(8.97)$ & $2.78(17.9)$ & $5.56(35.9)$ \\
\hline Mass of stack [lb $(\mathrm{kg})]$ & $1.15(0.523)$ & $1.74(0.789)$ & $2.83(1.28)$ \\
\hline Oxygen pressure [psi (MPa)] & $2000(13.8)$ & $2000(13.8)$ & $2000(13.8)$ \\
\hline Hydrogen pressure [psi (MPa)] & $1980(13.7)$ & $1980(13.7)$ & $1980(13.7)$ \\
\hline Water pressure [psia $(\mathrm{MPa})]$ & $15(0.10)$ & $15(0.10)$ & $15(0.10)$ \\
\hline Operating Temp. $\left[{ }^{\circ} \mathrm{F}\left({ }^{\circ} \mathrm{C}\right)\right]$ & $70-160(21-71)$ & $70-160(21-71)$ & $70-160(21-71)$ \\
\hline Net electrolysis at $120^{\circ} \mathrm{F}\left(49^{\circ} \mathrm{C}\right)$ & $2.8 \mathrm{~g} \mathrm{H}_{2} \mathrm{O} / \mathrm{hr}$ & $5.6 \mathrm{~g} \mathrm{H}_{2} \mathrm{O} / \mathrm{hr}$ & $11.1 \mathrm{~g} \mathrm{H}_{2} \mathrm{O} / \mathrm{hr}$ \\
\hline
\end{tabular}

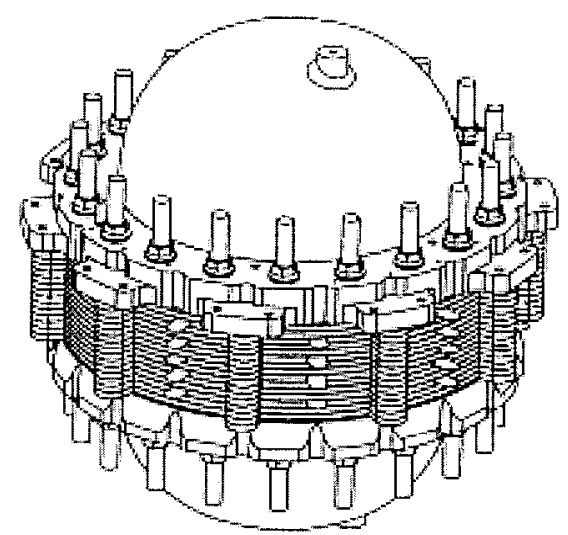

Figure 6. LLNL Design for 200 Watt Electrolyzer

and power tabs for electrical communication between individual cells, and with the power source. Individual cells are electrically isolated within the stack and connected externally in series. Stack weight in the $100 \mathrm{~W}$ unit was minimized with a combination of 16 cells each with a 0.019 $\mathrm{ft}^{2}\left(17.7 \mathrm{~cm}^{2}\right)$ active area. For this configuration, the cell outer diameter is 2.63 inches and end dome flange diameter is 3.57 inches.

The $200 \mathrm{~W}$ cell stack design is shown in Figure 6, and details of the trade study are given in Table 1 . Heat transfer sheets are composed of thin metal foils. Individual cells have a cavity which is ported to the end dome to maintain uniform compression and contact throughout the stack. This cavity removes the need for separate pressure pads, which helps reduce the weight of the cell stack. Stainless steel tie rods and lock nuts are preloaded to compress the seal area and contain the high pressures in the oxygen and hydrogen compartments. The three different sized units use 8,12 , and 20 tie rods respectively.

End dome assemblies are made of high strength-to-weight metal, and each includes a bladder with a metal pressure plate to transfer compressive forces to the active areas, maintaining uniform electrical contact throughout. The upper end domes are ported to allow for the inlet and outlet gases, which eliminates the need for a central fluid plate. This design saves on both the overall weight and size of the cell. The end dome operating pressure is 3000 psi $(20.7$ $\mathrm{MPa})$.

Concerns for the cells designed in this study include maintaining sufficient electrical contact through the active area of each cell. Since the membrane material tends to expand through the cell active area as the seal area on the membrane is compressed, it is difficult to estimate active area gaps and compression requirements prior to assembling hardware. Another concern is the material selection for the end dome bladders. The material performance during the life of the cell is critical. Other issues that await resolution after the assembly of a test unit include the amount of creep in the tie rods and membrane degradation.

Detailed drawings and models for the manufacture of cell parts for the 200 Watt system have been generated for the 2000 psi static water feed electrolyzer design. These drawings and models include: upper compression dome, lower compression dome, water screen frame, hydrogen screen frame, oxygen screen frame, membrane \& electrode, water feed barrier, separator frame, and insulator. Water is supplied from a surface tension tank or bladder tank at low pressure. (Space applications demand component technologies that operate in zero gravity, which imposes no further requirements on static feed cell designs but does demand special water tanks.) No rotating equipment, no moving parts except valve poppets (and water expulsion device motion) will be required to assist with the water supply for static feed cell designs. Heat is transported by conduction to a heatsink. The number of valves is minimized: just two valves, each one controlling one gas as it is transferred to a fuel cell (or rocket engine). Two electrolyzer gas outlet valves operate only on startup and when safing the system. Gas dryers are optional and may be employed to prevent ice formation inside equipment. (This consideration applies to many field-portable and outdoor applications as well as space applications. Note that only $\sim 0.2 \mathrm{Ibm}$ of water is delivered with the gases for 
each $100 \mathrm{lbm}$ of water electrolyzed at $120^{\circ} \mathrm{F}$. Dryers for $0.2 \mathrm{lbm}$ of water can weigh $\sim 3 \mathrm{lbm}$, so they may not be mass efficient. Freeze prevention by strategically placed heaters may be more mass effective. Lightweight regenerative dryers have been investigated by Hamilton Standard that employ PEM membranes and high pressure technology).

The $200 \mathrm{~W}$ static feed electrolyzer design can be modified for electric energy storage by making it into a reversible cell. The modifications include providing a temporary water storage volume into each cell to accommodate the product water produced during discharge periods. A mass increase of only $\sim 25 \%$ was estimated to achieve reversible operation. The crucial modification requires no additional mass: changing the cell oxygen electrode catalyst to one that is tailored for cell reversibility.

\section{Summary}

The Water Rocket suite of technologies is being integrated enroute to full technical readiness for a variety of space missions. The remaining technical challenges for this effort that must be addressed in order to achieve a space-qualified system are:

- Procurable zero-g URFC or electrolyzer that is lightweight and capable of high pressure gas generation

- Minimum mass gas tankage with acceptable permeation

- Packaging for voluminous $\mathrm{gH}_{2}$ storage that reduces structure mass

- Improved stoichiometric $\mathrm{gH}_{2} / \mathrm{gO}_{2}$ thrusters that achieve $\sim 400$ seconds Isp in vacuum

- Integration challenges including: operations, pressure specifications, water management, thermal management, electrical interfaces, range/Shuttle safety, and quality assurance

- Fluid management and transfer ancillaries, including: valves, regulators, relief devices, fill and vent ports, spill control, refueling operations, and water expulsion

- Develop a prototype system and test in a flight environment

- Test refueling strategies in a flight environment

The authors believe that these challenges can be met by a straightforward development program and the result will be significant new capabilities for future spacecraft

\section{Acknowledgments}

The authors would like to thank the U.S. Air Force Research Laboratory, the U.S. Department of Energy, United Technologies Hamilton Standard Division, Proton Energy Systems, Inc., the U.S. Air Force Academy, the
European Air Force Office of Research \& Development, NASA Glenn Research Center, Schafer Corporation, Thiokol Corporation, Aero Tec Laboratories, Southern Research Institute, Kaiser Marquardt, the RAND Corporation, William H. Nurick, and Mark J. Eckart.

This work was sponsored by the U.S. Government and performed by the University of California Lawrence Livermore National Laboratory under Contract W-7405Eng-48 with the U.S. Department of Energy.

\section{References}

1. P.J. Chludzinski, I.F. Danzig, A.P. Fickett, D.W. Craft, "Regenerative fuel cell development for satellite secondary power," General Electric Company Technical Report AFAPL-TR-73-34, June 1973.

2. F. Mitlitsky, A.H. Weisberg, and B. Myers, "Regenerative fuel cell systems," Energy \& Fuels, 12 (1), 56-71, January 12, 1998; UCRL-JC-128267 Rev 1; http://pubs. acs.org/isubscribe/journals/enfuem/jtext.cgi?enf uem/12/i01/html/ef970151w.html

3. F. Mitlitsky, B. Myers, and A.H. Weisberg, "Lightweight pressure vessels and unitized regenerative fuel cells," 1996 Fuel Cell Seminar, Orlando, FL, November 17-20, 1996; UCRL-JC-125220 (paper) and UCRL-MI-125220 (viewgraphs).

4. F. Mitlitsky, W.A. de Groot, L. Butler, and J.F. McElroy, "Integrated modular propulsion and regenerative electro-energy storage system (IMPRESS) for small satellites," AIAA Small Satellite Conference, September 16-20, 1996; UCRL-JC-125242.

5. F. Mitlitsky, B. Myers, A.H. Weisberg, and T.M. Molter, "Unitized regenerative fuel cell systems," 1998 Fuel Cell Seminar, Palm Springs, CA, November 16-19, 1998; UCRL-JC-130198 (paper) and UCRL-MI-130198 (viewgraphs).

6. A. Leonida, "Hydrogen-Oxygen $S P E^{\circledR}$ Electrochemical Devices for Zero-g Applications," Proceedings of the European Space Power Conference, Madrid, Spain, 1989 (ESA SP-294).

7. F. Mitlitsky, B. Myers, A. H. Weisberg, T.M. Molter, and W.F. Smith, "Reversible (Unitized) PEM Fuel Cell Devices," invited presentation, Portable Fuel Cells, Lucerne, Switzerland, June 21-24, 1999. 
8. F. Mitlitsky, "Water Rocket Technologies," invited presentation, US Embassy, Paris, France, December 1011, 1998; UCRL-MI-132628 Rev 1.

9. J. McElroy, A. Leonida, W. Smith, "High Differential Pressure SPE ${ }^{\circledR}$ Watcr Elcctrolyzcr," 28th Intcrsocicty Energy Conversion Engineering Conference (IECEC), Vol. 1, 1.1157-1.1162, August 9-13, 1993.

10. J.F. McElroy (Hamilton Standard); R.W. Humble (US Air Force Academy); W.A. de Groot and S.R. Oleson (FDC, Inc., N $\Lambda \mathrm{S} \Lambda$ LeRC); and F. Mitlitsky, $\Lambda . H$. Weisberg, B. Myers, and P.H. Carter II (LLNL), "Unitized Electrolysis Propulsion and Fuel Cell Power for Selected Satellite Missions," 33rd Intersociety Energy Conversion Engineering Conference (IECEC), Colorado Springs, CO, August 2-6, 1998 (IECEC-98-339).

11. P.H. Carter II, F. Mitlitsky, A.H. Weisberg, J.C. Whitehead, and R.W. Humble, "Design trade space for a Mars ascent vehicle for a Mars sample return mission," IAA Conference on Low-Cost Planetary Missions, Pasadena, CA, April 27-May 1, 1998; UCRL-JC-130277.

12. W.A. de Groot, L.A. Arrington, J.F. McElroy, F. Mitlitsky, A.H. Weisberg, P.H. Carter II, B. Myers, B.D. Reed, "Electrolysis propulsion for spacecraft applications," AIAA 97-2948, 33rd AIAA/ASME/SAE/ASEE Joint Propulsion Conference, July 7-9, 1997.

13. F. Mitlitsky, B. Myers, A.H. Weisberg, and A. I.eonida, "Applications and Development of High Pressure PEM Systems," invited presentation, Portable Fuel Cells International Conference, Lucerne, Switzerland, June 21 24 (1999); UCRL-JC-134539.

14. R.C. Stechman Jr. and J.G. Campbell, "Water electrolysis satellite propulsion system", The Marquardt Company, Van Nuys, CA, Technical Report AFRPL-TR72-132, January 1973.

15. F. Mitlitsky, A.H. Weisberg, and B. Myers, "Vehicular hydrogen storage using lightweight tanks (Regenerative fuel cell systems)," DOE Hydrogen Program Annual Review, Lakewood, CO, May 4-6 (1999); UCRLJC-134540.

16. A.G. Ledebuhr, J.F. Kordas, L.C. Ng, M.S. Jones, J.C. Whitehead, E. Breitfeller, R.J. Gaughan, M.D. Dittman, and B. Wilson., "Autonomous, agile microsatellites, and supporting technologies," AIAA-99-4537, AIAA Space Technology Conference \& Exposition, Albuquerque, NM, September 28-30, 1999.

\section{Biography}

Fred Mitlitsky received an Engineer Degree in 1986, an M.S. in 1983, and a B.S. in 1982, all in electrical engineering from Columbia University School of Engineering and Applied Science, New York City. He is a scnior scicntist and program manager of projects related to regenerative fuel cell systems for energy storage and propulsion. His recent innovations are enabling to a wide range of applications, including: spacecraft, high altitude long endurance (HALE) solar rechargeable aircraft/airships/ balloons, zero emission vehicles (ZEVs), portable power supplies, and stationary energy storage. He has been at Lawrence Livermore National Laboratory since 1982, he holds patents related to lightweight tankage, thin film fabrication, and high field magnets. He is the Water Rocket concept originator and program manager.

Andrew H. Weisberg received a Ph.D. in electrical engineering from Stanford University in 1991. He also received an Engineers Degree in 1985 in aeronautical and astronautical engineering and two M.S. degrees from Stanford University (applied physics in 1979 and electrical engineering in 1977). His undergraduate education at MIT resulted in the simultaneous award of three B.S. degrees in 1975 (electrical engineering, mechanical engineering, and aeronautics/astronautics). His wide range of innovations include significant advances in vehicular robotics, limbed locomotion, rocketry, UAVs, vehicle control systems, microfabrication, laser materials processing, superconducting magnets, pulsed chemical propulsion, solar aircraft powerplants, and energy storage. He was a founder of the first privately funded launch vehicle development venture (the first Amrock). He has been at Lawrence Livermore National Laboratory for 24 years.

Preston H. Carter received an M.S. in aerospace engineering from the University of Texas at Austin in 1986, and a B.S. in aeronautical and astronautical engineering from the University of Washington in 1980. $\mathrm{He}$ is currently the principal investigator and concept originator of the HyperSoar effort at Lawrence Livermore National Laboratory (LLNL). He joined LLNL in 1991 after nine years in the manned space and commercial space business sector. He also has two years experience at the Naval Weapons Center, China Lake, CA, working with airborne weapons systems and flight test. Other notable contributions include: Co-founder, with Alan Binder, of the Lunar Prospector mission, Member of the Clementine mission team, and lead engineer of several Shuttle payloads and several instrument payloads for satellite applications.

Michael D. Dittman received an M.S. in mechanical engineering, controls and dynamics from San Jose State

10

American Institute of Aeronautics and Astronautics 
University in 1993. He received a B.S. in mechanical engineering from California Polytechnic State University, San Luis Obispo. He worked at Space Systems/Loral from 1987-1997, where he was a lcad mechanical engineer for many satellite operations including alignments, assembly, integration and test, control mechanism design and development and spacecraft systems. He has been at LLNL since 1987 and has contributed to the design and development of microsatellite technologies including low pressure warm gas ACS systems.

Blake Myers received an S.M. in 1948 and a B.S. in 1946 in mechanical engineering from MIT. He is a registered nuclear engineer in California. He has been affiliated with Lawrence Livermore National Laboratory since its inception in 1952. He has a wide range of innovations and work experience related to aerospace, including: propulsion, energy storage, HALE solar rechargeable aircraft/airships/balloons, helical expanders, turbines, and nuclear ramjets. He has extensive expertise in designing and qualifying systems with a variety of potential hazards, including high pressure, high temperature, chemical reactions, and nuclear reactions.

Ronald W. Humble received a Ph.D. in 1986 and an M.S. in 1984 in aerospace engineering from the University of Texas at Austin. He received a B.S. in aeronautical and astronautical engineering from the University of Washington in 1980. He has 20 years experience in aerospace including flight test engineering work for the Canadian Airforce, turbine engine aerodynamics for Pratt $\&$ Whitney, and space hardware design experience at Space Industries, Inc. He was a professor at the University of Colorado at Colorado Springs, and is presently a professor at both the U.S. Air Force Academy in Colorado Springs and the Technical University of Delft in the Netherlands.

Jordin T. Kare received his Ph.D. in astrophysics from the University of California, Berkeley, in 1984. He has undergraduate degrees from MIT in physics and electrical engineering. From 1985 to 1996 he was a member of the Special Projects Group at Lawrence Livermore National Laboratory, where he worked on a range of projects involving lasers and space systems, including leading design efforts for an advanced space-based Synthetic Aperture Radar system. Since 1997 he has been a consultant to the aerospace industry on the architecture and design of advanced systems in areas of space and information technology. 